\title{
Rembetika as Embodiment of Istanbul's Margins
}

\section{Musical Landscapes in and of Transition}

Alex G. Papadopoulos

The story of Rembetika is as much a story about music in great cities of the Eastern Mediterranean and the Balkans - Istanbul among them - as it is a story about the spatialities of states and statecraft. Beginning in the 1830 s, the Ottoman imperial state continually "thickened," its capacities expanding gradually to regulate aspects of everyday life, mobility, settlement, and speech. While at times the Ottomans claimed that this augmented the right of all to the city through modernization, this took place in a vastly uneven manner, leaving large segments of the population and urban areas outside of a new-normative society and prosperity. Within the Empire and Balkan states in the region, the "long" nineteenth century would produce new connections to an incipient world economy (and hence, opportunities for social mobility), and simultaneously, new means of marginalization.

These social forces were nowhere more pronounced than in the imperial capital, Istanbul. The remaking of society would continue after the creation of the Turkish Republic in 1923, under the auspices of a Kemalist vision of Westernization and modernization. Rembetika as musical genre, state of mind, and practiced life, was one response by some marginalized subjects to such regional, statewide, and urban upheavals.

I suggest that Rembetika is music in transition, in the sense that Maria Todorova imagines the Balkans and Balkanism as consti- 
tuting a transitional concept - something not quite non-European (Todorova, 1997: 17-18). Rembetika is also music of transition, in the sense that it turned into songs the realities of life in the urban margins at a time of profound. In this chapter I explore Rembetika (the musical genre and the life mode) as co-constructive of Istanbul's socio-spatial margins, and as a phenomenon coterminous with the twilight of the Ottoman Empire, the emergence of the Turkish Republic, and the Greek diaspora that it triggered. Specifically, I focus on the scalar linkages between the body of the rembetes, which I consider from a Merleau-Ponty body schema perspective, and the scales of the mahalle (the neighborhood), the city, and the broader region, which encompasses Istanbul and the Asia Minor littoral as points of diffusion of Rembetika to Greek gateway cities, such as Thessaloniki, Athens, and Pireaus. Polarities define the Rembetika phenomenon: The neglected urban margins versus the rapidly changing urban core; the loss of an Empire and the gain of a Republic; Turkey and Greece (as origin and destination regions of Rembetika) co-constructed geopolitically by the Great War and its aftermath; and the voice (and musics) of "the Orient" versus those of the West. Ultimately, I claim that Rembetika was derived of crises of modernization, Westernization, and geopolitical happenstance at the turn of the 19th century and the first half of the 2oth in urban places like Istanbul and Izmir. It gave voice, represented the embodiment of the urban margin, and provided solace and inclusivity to an otherwise invisible and excluded urban minority population.

The consensus is that true rembetes disappeared sometime past the midpoint of the 2oth century along with the politicalsocial circumstances that gave rise to them. One might ask what purpose serves today commodified Rembetika music, as it endures mostly in Greece and vestigially in Turkey. Is it a cultural form that amount to more than entertainment, perhaps becoming a contemporary medium of an inclusive politics? I should think not. For all its extraordinary political and social charge in the genre's formative decades, the decoupling of urban marginality from the making 
and performance of Rembetika since the 1960 s has rendered it into a classical, popular musical genre as opposed to a subversive one. New forms of music, as Kevin Yildirim shows in his study of hip hop culture in Sulukule in this volume, have emerged to serve as commentary on, and resistance to exclusion, and as community connective tissue and a link between marginalized communities and the world.

\section{Rembetika - What and When}

Those who know about the Rembetika music genre intimately the musicians themselves and those who inhabited the world that Rembetika captured in verse, music, and movement - describe it as a fully immersive experience. Petropoulos writes that " $t$ there is no rembetic way of thinking. There is a rembetic way of living" (Petropoulos, 1991: 12). Stathis Gauntlett dates its beginnings to the mid-to late 19th century (Gauntlett, 2001: 24), while Petropoulos suggests that the genesis and the historical and artistic arcs of Rembetika originated in a creative milieu in the Ottoman Empire (later Turkey) and in Greece of the end of the 19th and first half of the 2oth centuries. Savvopoulos points out that "Rembetika" is used for the first time in a gramophone record label between 1910-13 (Savvopoulos, 2006: 14). In any case the Rembetika culture milieu stood at a considerable distance from both Turkish and Greek educational institutions, music forms, and performance spaces where mainstream (including state-sanctioned) culture was produced. Further, Petropoulos suggests that Rembetika-as-life was a strongly sensory and intensely somatic experience. In both senses, it stands apart from the musical mainstream of a Westernizing Ottoman Empire and Turkish Republic. Most importantly, however, Rembetika, not unlike the music of the âşıss, is a musical tradition in transition, buffeted and shaped by modernity and nationalism (Samson, 2013: 73-75). 
This significant social distance, on the one hand, between rembetes (as musicians) and rembetes as those members of the general public who lived lives that reflected and inspired the Rembetika, and on the other hand, mainstream culture, begs the question of whether cultural marginality mapped on socio-economic marginality, and by extension, on socio-spatial marginality. And, indeed, this is the case. Rembetika music riffed on, lamented, mocked, attacked, and sung about the limitations and exclusions, injustices and cruel punishments (including incarceration), and anomie that mainstream society imposed upon the socially marginalized. And while there is no absence in the songs of self-blame for interpersonal woes (referencing family members, lovers, pack brothers, the butcher and the tavern keeper), there is also no doubt that "society" (through its structures and their agents: the police, the state, the warden, the wealthy, and those generally in control) bears blame for the compromised position of those excluded. Absent a Marxian class-consciousness, these polarities are not expressed by rembetes in terms of a class struggle. Yet I would argue that one can neither call the rembetic world a reflection of the lumpen proletariat, as the rembetic phenomenon manifested itself geographically outside the European industrial capitalist core. ${ }^{1}$

1 Peter Manuel disagrees on this point. He writes that "[t]his music, called rebetika [or rembetika], was a product of the lumpen proletarian subculture that emerged during this dramatic urbanization process. While some of the migrants were dispossessed peasants from the Greek countryside, the majority were former inhabitants of Smyrna and Istanbul expelled in 1922. These latter brought with them their own Turkish-influenced urban musics, which eventually evolved into a commercial Greek popular music in conjunction with the rise of the mass media" (Manuel, 82). 
Figure 1: Rembetes are posing for the camera in a small commercial street of the low-rent Karaiskaki neighborhood, which stood on an unincorporated swath of land between Athens and Piraeus reserved for refugee settlements - ca. 1937 (Petropoulos, 1991: 424)

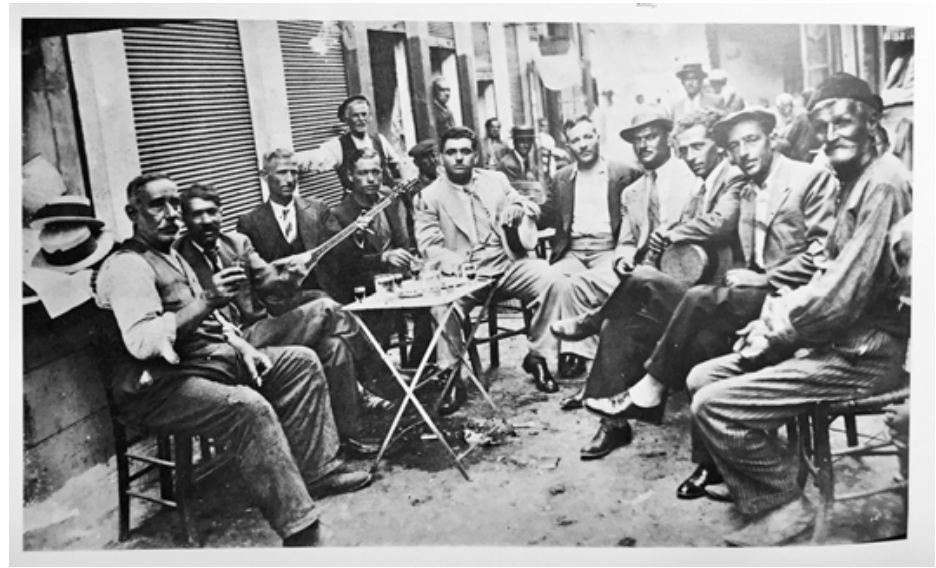

Kedros Editions, with permission

The etymology and origins of the word rembetes (or rebetes) is in dispute. Popular imagination claims that comes from the Turkish term for "outlaw" (rebet), although Gauntlett, who is credited with the most systematic study of the term, questions it and any Turkish derivation of the term, suggesting a number of alternative sources that include Kurdish, Albanian, and Serbo-Croatian (Gauntlett 2001: 40-43).

Rembetes, then, can be described as mostly Greek ethnics who occupied the ranks of the socially marginalized in cities like Istanbul and Izmir, and who migrated and brought their musical culture to refugee camps in big Greek cities like Thessaloniki, Pireaus, and Athens (gateway cities for the population exchangees of the Treaty of Lausanne of 1922).

As a musical genre, and following the population exchanges, Rembetika shed some of its Turkish modes in favor of more 
European and harmony-oriented ones, especially under the influence of Vassilis Tsitsanis (Manuel, 83). Rembetika as music culture, then, gives voice to exclusion and simultaneously "place-makes" and creates artistic/performance spaces for inclusion among those who perceive themselves as being left behind.

\section{Theorizing the Rembetes Body}

The life, activities, and daily paths of rembetes, as persons inhabiting the urban margin, are profoundly embodied. Rembetika's fusion of lyrics, music, and dance render bodyspace into the elemental geographic scale. Bodyspace, in this case, includes the human body itself (which is socially-structurally excluded by normative society), as well as the dynamic and plastic envelope surrounding it. The bodies of the rembetes (adornments and accessories included) occupy and construct hyper-local space as an intimate bubble of inclusion as they lounge, move, swagger, gyrate, love/sex, agonize against, or produce creatively with other bodies, forming dyadic and multi-body spaces, most often in defiance of convention, charter institutions, and state power. Thus the manner in which the rembetes body is implicated in expressive and transgressive acts is constructive of inclusion and a reaction to exclusion.

Merleau-Ponty's concept of body schema is revealing here. He writes that the spatiality of the body is not positional but situational: it extends beyond bodily awareness as the "mere result of associations established in the course of experience, but rather the global awareness of [one's] posture in the inter-sensory world, a 'form' in Gestalt psychology's sense of the word" (Merleau-Ponty, 2013: Kindle 3549-3551). By extension "habit [as in habitual conduct in space] expresses the power we have of dilating our being-in-the-world, or of altering our existence through incorporating new instruments" (Ibid: Kindle 4402-4403). Simone de Beauvoir similarly suggests, that the lived body "is not a thing, it is a situation: it is [one's] grasp on the world" (de Beauvoir, 2010: 46). The construct is useful in 
understanding the rembetes' embodied life although Merlau-Ponty's and de Beauvoir's understanding of a situational body schema that "dilates into the world", or alternatively "graps" (as in pulling one's self forward or, at least, seizing and comprehending) the world, is best an description of French post-World War II subjectivity: a time of growth and opportunity, an environment of near-endless possibilities for the working and middle classes.

The body schema of the Istanbul marginalized, the rembetes included, possessing little power, dilates into a much scaled-down world, or when it dilates transnationally, it is at the consequence of displacement. Machinists' and leather workers', porters' and fruit peddlers', carriage drivers' and fishermen's bodies in Ara Güler's totemic photographs of Istanbul in the 1950 s and 1960 s are emblematic of that embodiment of labor. The porters of scrap metal in his 1965 photograph from Kazliçeşme - Istanbul's iconic place of industry and stockyards - are transformed-into-worker-ants, bearing outsize loads.

Figure 2: Porters in Kazliçeşme industrial district (Ara Güler, 1965)

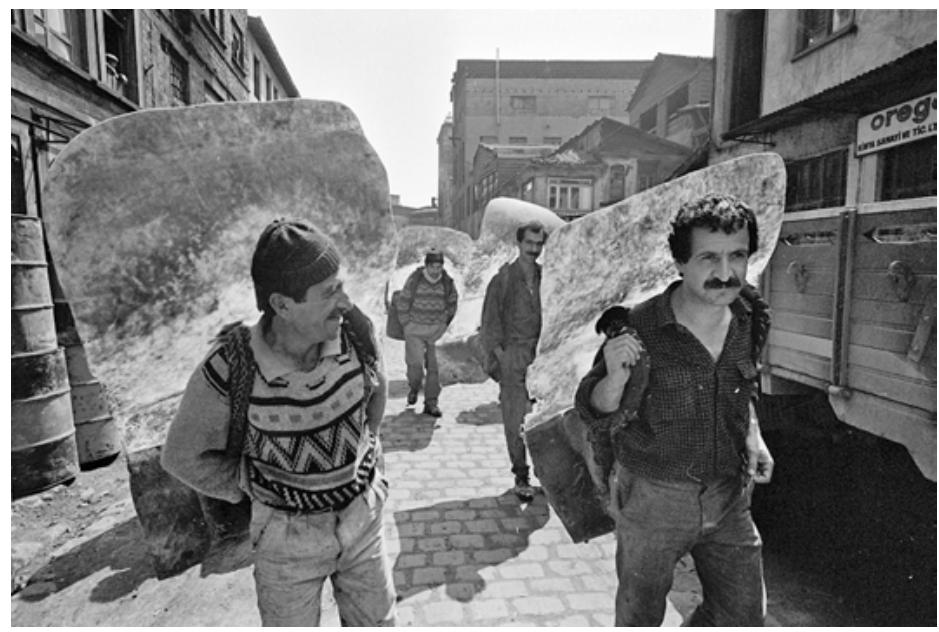

Magnum Photos, with permission 
Recalling Merlaeu-Ponty's language, the porter in Eminönü, depicted in Güler's 1958 photograph carrying a huge barrel on his back, is (contorted and) transformed situationally into a mollusklike hybrid. The barrel as an incorporated instrument extends the porter's instrumentality, although not necessarily in a manner that extends his reach into the world. His is a strongly embodied life of highly circumscribed possibilities. Accordingly, in classic cultural geographic terms, we can imagine the rembetes' laboring body implicated in a genre-de-vie (a mode of living and transforming the local) the contours of which are defined by the structural possibilities and limitations of Istanbul margins (Vidal de la Blache, 1922: 115-17). ${ }^{2}$

The rembetes' body schema, then, is co-constructed with the Ottoman-world-in-transition-to-modernity, and as such reflects and dilates into the changing city it inhabits, at least so far as the city's socio-spatial state of marginality would allow. The more physically

2 Refining his regional concept of genre de vis in his Les Principes de Géographie humaine (1922), Paul Vidal de la Blache imagined the delimitation of regions on the basis of "modes of living/livelihood" constructed out of discursive action between society and nature: “... modes de groupements sociaux, originairement sortis de la collaboration de la nature et des hommes, mais de plus en plus émancipés de l'influence directe des milieux. A l'aide de matériaux et d'éléments pris dans la nature ambiante, il (l'homme) a réussi, non d'un seul coup, mais par une transmission héréditaire de procédés et d'inventions, à constituer quelque chose de méthodique qui assure son existence et qui lui fait un milieu à son usage" (115-16). The takeaway here is that de la Blache, whose work was France-centered and substantially rural-focused, is describing a world in the throes of modernization. His genre de vie device situates action créatrice (203) and part d'invention (116) as essential mechanisms of, and for change, especially in the presence of external stressors. I suggest here that Rembetika is both descriptive of, and a catalyst for, the regionalization of some of Istanbul's margins, in the sense that its action créatrice - albeit contrarian to the mainstream - makes places of inclusion and systematizes resistance to exclusion. 
bound to one's corporeal (embodied) self one is, when toiling through a life where dirt, blood and guts (sometimes literally) are defining modalities, the less socially valuable one becomes to a Westernizing society that super-valorizes disembodied Reason. In that sense, the distressed rembetes body embodies the urban margins. Mechthild Hart notes that “ $[t]$ he further a person's class, color, national origin, or gender removes [him or] her from the category that symbolizes the pinnacle of disembodied purity [the Western, patriarchal ideal], the closer she gets to the merely physical or bodily" (Hart, 2013: 51). Explaining further the effects of mind-body dualism and polarity, Hart claims that "[w]hile the general social value shrinks or disappears for these bodies or body-carers, it grows for those categorically most removed from them" (Ibid). She is not necessarily thinking of "removed at a distance" in strictly geographical terms, but that is certainly so in this case. In extremis the undisciplined rembetes body may be incarcerated for violent acts, use of narcotics, or mouthing off at power. On an ordinary day, it circulates within eccentricto-urban-renewal, low-rent neighborhoods, becoming implicated in minor, localized, and at times 'outlaw' circuits of capital.

In the volatile decades that preceded the Great War and the end of empire, the lives of those in the socio-spatial margins of Istanbul and the Rembetika milieu, were going to be slowly drawn from worldlessness (as Hannah Arendt calls the muteness and anonymity of those who live and toil in the private realm - in our case the traditional mahalle) (Arendt, 1958: 118) to an in-betweenness that, "defies the public-private" division" (Hart, 2013: 64). Living close to the ground, in neighborhoods that were not the target of urban civic or industrial modernization, the mass of socially marginal millet members (Greeks/Rum, Jews, and Armenians) worked in small, scant value-added, and strongly embodied trades and traditional occupations. ${ }^{3}$ That dolorous marginality or in-betweenness was the muse of Rembetika music and mirrored the rembetes' body schema

3 | It would be incorrect to claim that anomie was the domain of the notorious among them - although, no doubt, there were rembetes who were notorious 
in songs about love and sex, alienation and life in foreign lands, death and being condemned to Hades, about poverty, prison life, drugs, pride, the mother, and hymns to the beauty of the Orient.

\section{Modeling the Rembetes Body}

Although Rembetika culture is closely identified with the Rembetika musical genre, Petropoulos, in his classic ethnography, claims the iconic rembetes in the Istanbul, Izmir, or Salonikan 'hood is not by definition a café-amané singer or a musician, though he (and occasionally she - a rembetissa) is steeped in the music, verse, and dance of the genre. Thus, a rembetes may communicate his or her state of mind through dance - the idiosyncratic "zeybekiko" solo dance, the "hasapiko" (or so-called butchers' dance) danced with peers, or the "tsifteteli", though, in this latter case, only occasionally and selectively given that dance's hyper-sensuous, feminine gyrations (Petropoulos, 1990: 7-62).

A rembetes has not necessarily served time in prison, though oftentimes he has, or at the very least has associated with those who have been imprisoned. He is armed and inclined to use physical force, as he navigates the urban demimonde of Istanbul or Salonika, and especially the nocturnal haunts where rembetes play their music. He is known to appreciate the pleasures of hashish, calls it by various terms of endearment, and relies on it as chemical release from daily and long-term wretchedness. In fact, if also a musician, he holds the cigarette in a signature-rembetic way that accommodates playing his stringed instrument.

Although, patently anti-bourgeois, a rembetes does not identify with the Left, and consequently has, at times, attracted the harsh critique of Greek leftists for this absence of discernable class-consciousness. The Communist Party of Greece derided Rembetika as "a weapon for the

thieves and purveyors of protection and prostitution. As such they benefitted from disabilities of, and lapses in the gaze of police and the fiscal state. 
subjugation of the masses in the hands of their oppressors [...] [a manifestation of] a counterrevolutionary lumpen [...] the Turkish cultural fringe" (Vlisidis, 2011: 64). Only as the Greek Civil War (1946-49) drew to a close, would some intellectuals of the Left attempt to reconcile communist ideology with the counter establishment sentiments of Rembetika. Writing in the Party's official newspaper O Rizospastis on January 28, 1947, Foibos Anoyeianakis calls Rembetika "contemporary," "popular" [referring to its social profundity rather than merely its entertainment appeal], "urban songs" (Anoyeianakis, 1947). Yet in spite of these partisan divisions, the rembetes clearly has a heightened sense of social justice, at least as other members of his immediate environment are concerned. Per the Rembetika lore, he does not have a steady job, instead walking a fine line between lawfulness and criminality. Contrary to that lore, some of the greats of Rembetika music, notably Tsitsanis and Vamvakaris, held blue-collar jobs.

Figure 3: Drug paraphernalia, knives, and guns confiscated by police authorities (Petropoulos, 1991: 439)

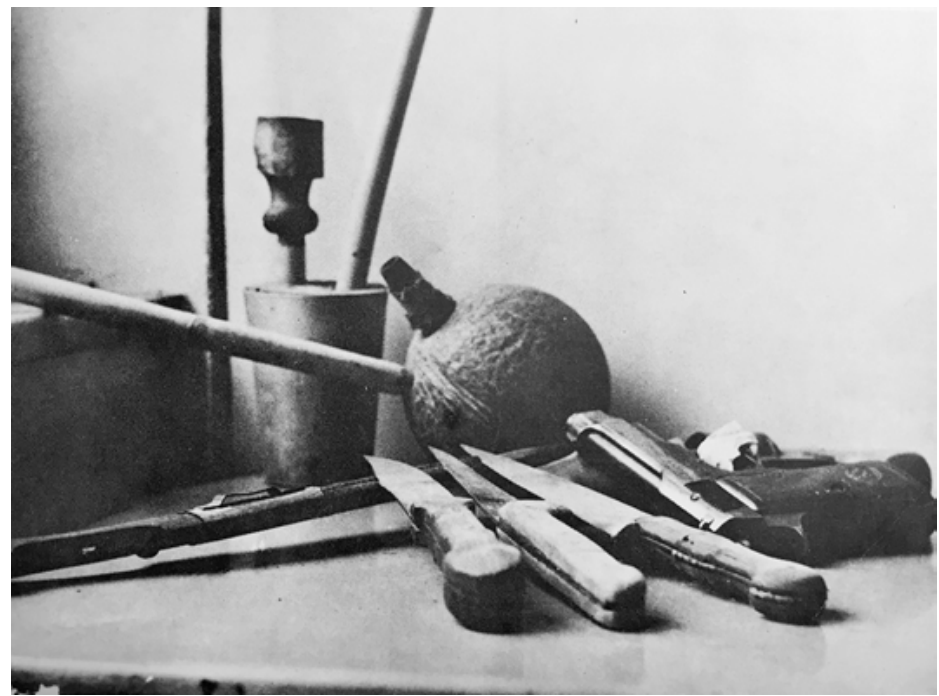

Kedros Editions, with permission 
The rembetes is careful about his manner of dress, if only to make sure that the weapons are properly concealed. We cannot call him a dandy in the traditional sense, although his attire can be elaborate. That mode of dress is distinctive enough that the type is recognizable on the street. A rembetes may cut an impressive figure on the street in his working class mahalle or neighborhood, the same way a fedora- and zoot-suit wearer would have in the United States of the 1940 s.

According to Petropoulos, the relationship of a rembetes to family is almost always fraught. A rembetes would only rarely sing about his father or the father figure, but the mother is consistently held up as precious but tormented. Marital relations also fall outside the social conventions of the twilight of the Empire and the Republic that followed it. A true rembetes would never marry, defining himself, invariably, in opposition to bourgeois values and lifestyle. That was not an absolute, of course, as denizens of the Rembetika universe would cross the porous boundaries into straight society. Women featured greatly, in the Rembetika patriarchy, as lovers, as implicated in dramatic circumstances, being unattainable, unfaithful, or sexually uncontainable. A rembetes may also appreciate the sexual favors of younger men and boys without incurring the social disapproval of his peers, although the maintenance of masculinity is imperative. Facial hair - specifically, moustaches - is mandatory.

Lastly, a rembetes' speech can be exaggerated, mockingly misappropriating 'high Greek', the archaizing idiom adopted in the 19th century by elites of the Modern Greek state. He would mix it with rembetes argot or slang, producing an encoded idiom fully comprehensible only to other members of Rembetika society. 
Figure 4: The famous rembetes Yiannis Papaioannou dances the Zeybekiko in an Istanbul café Aman, ca. 1950 (Petropoulos, 1991: 483)

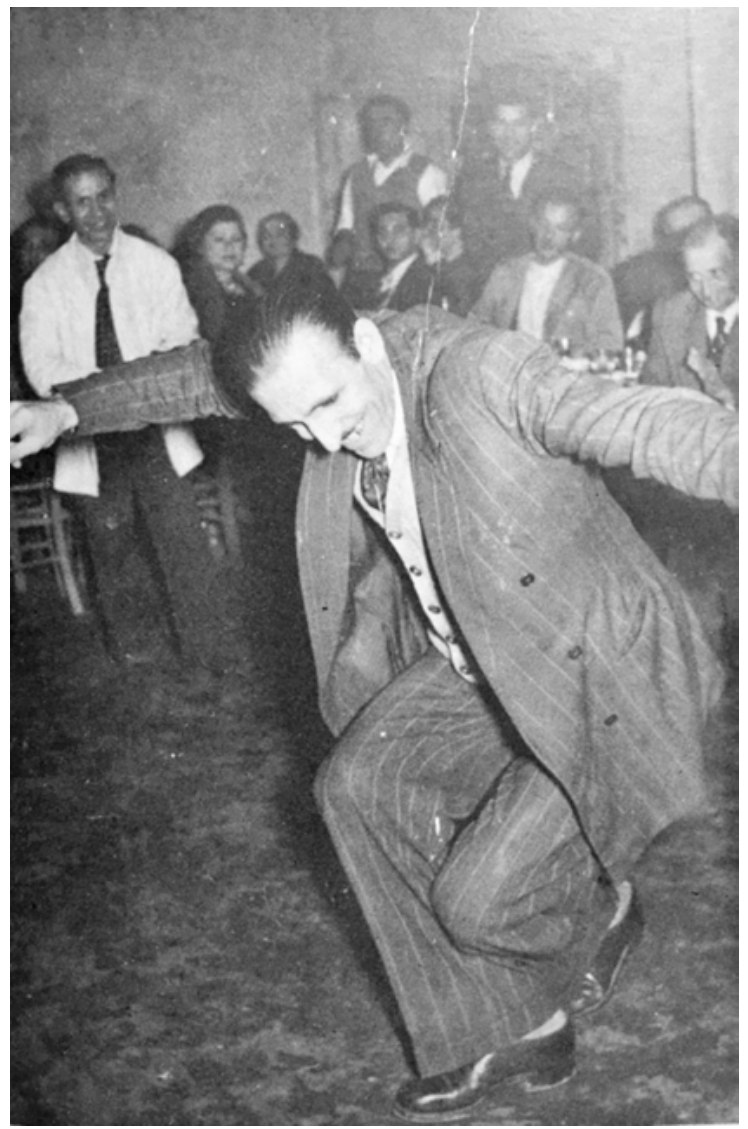

Kedros Editions, with permission

In all, to the eyes and ears of Western spectators, a rembetes would resemble somebody the French would call 'mec' or the Americans 'a soulful dude'. Thus, this list of rembetes attributes describes a person and an urban social fragment - not quite a class of people - 
who is defined by socio-spatial marginality. The rembetes' marginality may involve prison life, unemployment and poverty, use of mind-altering substances, the breaking of social conventions and taboos, and sequestration in some of the poorest districts in the city. He is a transgressor, who the marginalized masses may not dare to follow in his seemingly unbounded license. If they did, it would be in a dive bar, tavern or club, sharing hash and abstracting on the Rembetika zeitgeist by singing along, reserving a solo dance, and perhaps indulging in thoughts of taking revenge upon one's enemies.

It would appear that the rembetes, their lives, and their iconography - obscured by the absence of official sources and accounts were made for caricaturing. Much information about the early decades of Rembetika, before 1922, comes from Rembetika musicians, who narrated stories of their lives to music magazines and, occasionally, to biographers. Photographs from Rembetika haunts are scarce, and those, which survive, are of post-1922 Greek provenance. ${ }^{4}$ Recent scholarship has put in doubt some of the claims made in Petropoulos' classic ethnography and have long been embraced as iconic of Rembetika life. Alexatos suggests that the iconic rembetes is, at least to some degree, the creation of the Greek middle classes. Both titillated and enthralled by the notoriety and contrarian behavior of rembetes, he claims a popular imagination crystallized some of rembetes' most over-the-top characteristics (Alexatos, 2014: 36). ${ }^{5}$

4 Illias Petropoulos has collected a considerable number of these surviving images in his 1991 Rembetika Songs, Athens: Kedros.

5 | Kostas Ferris' film Rebetiko (Silver Bear Award, Berlin International Festival, 1984), which was based on the life of singer Mara Ninou, transformed rembetika into an international musical sensation, while further reinforcing the anti-hero of the demimonde image of rembetes. 


\section{Rembetika as Transgression, Enemy of the State}

The temporal and spatial settings of the Rembetika phenomenon allow us to triangulate 'the urban' with inclusion and exclusion by looking at Rembetika spaces, performances of Rembetika culture, and considering how they connected to broader society and to a state that was increasingly attempting to regulate behavior and culture. The very emergence of the rembetes, as a transgressive social-artistic type - be it in the last years of the Ottoman Empire, during the Kemalist rampage against the culture of the "Orient", or the Metaxas dictatorship in Greece of the 1930s - was extraordinary. The phenomenon attests to the power of music to articulate resistance to political power and oppression. Petropoulos has pointed out that the rembetes life and cultural mode were at once a construction of marginality and a choice (Petropoulos, 1990: 10). Vlisidis claims that both aspects of Rembetika were perceived as threatening to the social and political order and, by extension, to Greek and Turkish elites. Lending voice to the oppressed, even when it was about affairs of the heart or the bedroom, ran counter to state cultures that relied heavily on the regulation of speech to protect their nationalist brand. During the Metaxas dictatorial regime, laws were passed in quick succession aimed at not just containing but annihilating what was described as "music that assaults the public sentiment, corrupts the aesthetic sensibility of the population, and adulterates and perverts the original spirit of Greece's musical tradition." The Directorate of Popular Enlightenment commanded the banning of all gramophone Rembetika records in circulation and demanded that all existing gramophone molds be submitted for destruction (Vlisidis, 2004: 56-57). The legislation fell short of banning all live performances, as that would have required the close policing of marginalized neighborhoods - a task beyond the resources, though not the stomach, of what was essentially a fascist regime. Although polite Athenian society had long disapproved of the "Oriental" rembetiko qua amané as "anachronistic", "immoral", and embarrassingly reminiscent of 
Greece's Ottoman antecedents, it was the Metaxas regime, which, unwittingly, elevated it to political art.

Embedded spatially in a hostile state, the performance of loud, rude, lewd or profane Rembetika songs in an underground club (a teké, so called, evoking the spiritual spaces of Sufi Islam), or their broadcast on the gramophone, is, I would claim, the quintessence of psychical self-care and wellbeing. Rembetika's effects might appear improbable and fleeting, under the circumstances, lasting only until the smack cigarette burns out and the soulful dance ends. Importantly, then, the true rembetes life can only happen in the socially polarized city, where there are vast neighborhoods of dispossessed refugees who would worship the rembetes and the rembetissa for giving voice to marginalized lives. The old rembetes composer, Yorgos Rovertakis, said that "[r]embetika songs were written by rembetes for rembetes... The rembetes was a man who had a sorrow and threw it out" (Holst, 1994, 14). To wit, Rembetika are no longer Rembetika once extracted from the space-time that embodied it. It is ontologically transformed when performed on cassette, CD, or mainstream society club or orchestra hall, hence my earlier statement that today it has become "a classic".

\section{ISTANBUL'S LANDSCAPES IN TRANSITION}

\section{The Temporal Fix}

The earliest mentions of Rembetika date to the middle of the nineteenth century (Butterworth/Schneider: 13), as noted before. Holst, who interviewed in the 1970 s several old rembetes who remember the Great War and its aftermath describe the origins as follows: "[R]embetika appeared toward the end of the 19th century in a number of urban centres where Greeks lived. About this time musical cafés appeared in towns like Athens and Pireaus, Larissa, Hermoupolis on the island of Syros, Thessalonika, still under Turkish domination, Smyrna, on the Turkish coast, and Constantinople [Istanbul] (Holst, 
1994: 20). The chronological arc that defines its origins, its development into an important popular music genre, and its eventual demise through its transformation into a commodified type of music lasted approximately a century. The decline of Rembetika in Turkey and its further Hellenization would be catalyzed by the population exchanges of 1922. In important part, following the 1955 anti-Greek riots and the 1964 expulsion of most of Istanbul Greeks, the Istanbulcentering of that musical subculture came to an abrupt end.

Without question, structural reforms in the second half of the 19th century and beyond signaled a Western assault, with the reluctant complicity of the Divan, upon the cultural and social diversity of the Ottoman cosmopolis, along with a devalorizing of genres de vie and cultural production that did not cohere to the inexorable forces of industrial capitalism.

One of the Tanzimat Charter's critical objectives was the refashioning of important Ottoman cities, and especially the imperial capital, in accordance to the morphological sensibilities of formal planning, with Haussmanization adopted as the master paradigm by the end of the 19th century. The First Building Regulation of 1848 (Birinci Ebniye Nizamnamesi) articulated new methods for parcellation and the widening and standardization of streets, while the expropriation regulations of 1856 created the legal environment for an urban palimpsest capable of erasing entire neighborhoods from the urban plan in the service of modernization (Aksoylu/Ateş, 2013: 14). To paraphrase the Communist Manifesto, a great deal of what was solid melted into air. And further, gradual revolutionizing of production (especially in Istanbul), surging disturbance of all social conditions, mounting uncertainty and agitation, all served to distinguish the end of the 19th century from the pre-Tanzimat reform era. Much of the "fixed, fast-frozen relations," with their train of ancient and venerable prejudices and opinions, were gradually "swept away, all new-formed ones become antiquated before they can ossify."

6 | The classic text reads as follows: "Constant revolutionizing of production, uninterrupted disturbance of all social conditions, everlasting uncer- 
Ottoman places and zones of urban stability, even if poor, either became potential targets for urban modernization, or ended up as destinations for those internally displaced by attempts at Haussmanization. ${ }^{7}$

This tension (even fissure) between the stability and constancy of past cultural, political, and urban practices and the uncertainty and social convulsions produced by creeping modernity animated the storytelling, through song and dance, of the rembetes, whose stories were at times about interiority (psychic and emotive paroxysms caused by yearning or loss) and at others, about exteriorizing resistance to a violent and indifferent society and state. Following María Lugones, storytelling then (or singing and dancing, in this

tainty and agitation distinguish the bourgeois epoch from all earlier ones. All fixed, fast-frozen relations, with their train of ancient and venerable prejudices and opinions, are swept away, all new-formed ones become antiquated before they can ossify. All that is solid melts into air, all that is holy is profaned, and man is at last compelled to face with sober senses his real conditions of life, and his relations with his kind. The need of a constantly expanding market for its products chases the bourgeoisie over the entire surface of the globe. It must nestle everywhere, settle everywhere, establish connections everywhere." (Manifesto of the Communist Party: https:// www.marxists.org/archive/marx/works/download/pdf/Manifesto.pdf, p. 16.) 7 | As the Haussmanization paradigm illustrated in the case of Paris, massive financial resources needed to be injected into urban transformation, resources that were not available in the case of Ottoman Istanbul. As Çelik explains, western planners, such as Joseph Antoine Bouvard, were invited to vision major projects that would have created a regular town plan. Boulevards and squares in the French planning sensibility were meant to modernize the capital. The projects were geographically focused on prestigious quarters of the Old City (Hippodrome, Beyazit Square, Validé Square, and the Galata Bridge). The abstract character of these plans in addition to capital scarcity, made these ambitious plans improbable if not impossible. Clearly neighborhoods of lesser political and economic importance would have remained entirely outside the scope of such visioning. 
case) can be "emancipatory sense-making" for those who live in the "in-between" of multiple worlds/selves (Lugones, 2003: 210) ${ }^{8}$

When Edmondo De Amicis' travel book Constantinople was published in 1877 , the Ottoman Empire had been on the road to structural economic reform for decades. Already in the first three decades of the 19th century, economic changes in the industrializing world were hastening a new balance of power and ordering of states that placed the Empire at a relative disadvantage. The substantial, if not massive, collateral impacts of economic change on its geopolitics, its social-cultural make-up and dynamics, and on the urban environment were felt most strongly in Istanbul. By 1877 the Empire was burdened by enormous debt owed to European banks and incurred primarily during the Crimean War. Lands in the Balkans and the Caucasus were lost to Austro-Hungarian and Russian aggression. The losses were limited through British advocacy, although Britain leveraged its position as mediator in order to gain territorial concessions in Cyprus and Egypt. And as the territorial integrity and geographical extent of the Empire became increasingly destabilized and reduced, Istanbul - ever the hinge of the Empire - continued to grow demographically and become increasingly culturally complex and dynamic.

New commercial linkages to successor states like Greece, Bulgaria and Romania, re-segmented and alimented the cultural milieu with

8| Mechthild Hart draws on Lugones' work which studies the tensions and contradictions that underwrite the lives and itineraries of Latina domestic workers in the Unites States, who through their embodied labor are "resistively moving in an in-between space that defies the publicprivate division". Not "at home", yet at the home of their employers, the domestic workers occupy an "in-between" space that defines conventional definition. This "in-betweenness" represents common experiential ground among domestic workers, who, once in a place where they can share their stories, lose their muteness, recollect, gain voice, and engage in liberatory action by publically acknowledging their "passion, anger, fury, but also joy and delight in hearing others confirm their experiences" (Hart, 2013: 64). 
new languages and artistic expressions. Old antagonists, such as the Italians and the Russians, and new ones, primarily the French, the British and the Germans, articulated the Istanbul "local," be it the port, the new industries, the cultural sites (now in the Grand Tour), the semt (the urban district), and even the common mahalle (the neighborhood), to new circuits of capital and cultural exchange. Yet, at the time it was unclear what Istanbul's future would look like. While resting against a rail on the Galata Bridge, De Amicis mused about what it might look like in the 21st century:

I see her, the Constantinople of the future, that London of the East, rising up in gloomy, oppressive majesty upon the ruins of the loveliest city on earth. The hills will be leveled, the groves cut down, the brightly painted houses demolished; the horizon will be closed on every side by long, rigid lines of apartment blocks, workers' housing and workshops, interspersed with a thousand factory chimneys and clock towers with pyramid-shaped roofs. (De Amicis, 1878: 72).

Indeed, for the Western European subject living in the advancing industrial capitalist era of the 1870 s, smokestack industrialization and the new disciplines and cadence of industrial working life would have appeared inevitable. In a Marxian sense, at the time, capital did appear unstoppable in its drive to reproduce the landscapes of Sheffield, Liège and Dusseldorf all across the world. In the case of the Empire, industrial transformation - albeit limited - was geographically centered in Istanbul.

De Amicis continues imagining ...

Long, straight, regular avenues will divide Stamboul, gridlike, into ten thousand enormous districts; telegraph wires will criss-cross over the roofs of the noisy city like a vast spider's web; a black torrent of top hats and caps will flow all day long over the bridge of the Sultana Valide; the mysterious hill of the Seraglio will be a zoological park; the Castle of the Seven Towers a prison, the Hebdomon a museum of natural history: the whole will be solid, 
geometrical, useful, grey and ugly, and a great dark, ever-present cloud will cover the beautiful skies of Thrace ... (Ibid).

De Amicis' stock imagery of the European industrial town of his era could, of course, have as well been referring to Genoa or Milan. The strong conviction of his words says more about him as a creature of the Industrial Revolution than about the evolutionary path Istanbul objectively was taking at the time. Still, his description is important because it marked a time of extraordinary possibilities for the Empire and its capital. And at a later point in the book, De Amicis puts his journalist hat back on, giving an eyewitness report of the music and theater scenes at ground level. His orientalist language surprises and offends, but we can read through it to extract useful information about the urban music scene:

At Constantinople, anyone with a strong stomach may pass the evening at the theater and take his choice from a host of fleapits of every kind, many of which have gardens and sell beer ... The Turks ... prefer to frequent the places where certain French actresses, painted, half naked and impudent, perform popular songs to the accompaniment of a tinpot orchestra. One of these theaters was the Alhambra, in the main street of Péra; one long room which was always full with a sea of red fezzes from the stage to the door. It is impossible to describe the kind of songs they sang and the gestures which accompanied them as these intrepid ladies strove to make their Turkish audience understand the innuendoes (De Amicis, 1878: 90-1).

The conflation of "fez-bearer" with "Turk" is misleading as the fez was worn quite widely across ethnicities, religions and classes at that time. It further reveals De Amicis' cultural naiveté. What is useful, however, is the confirmation of the Péra district as an epicenter of 'bright lights' establishments, of the presence of a broadly qualitative range of entertainment venues, some even bearing grandiose names like Alhambra, and of the nature of entertainment, which clearly appeared licentious, at least to the eyes of Western European Victorians. 
Figure 5: In frames 5 and 6 of the 1890-1910 multi-frame Sebah a Joaillier Panorama de Constantinople, pris de La Tour de Galata, we observe a great volume of shipping and the dense built fabric in the Golden Horn

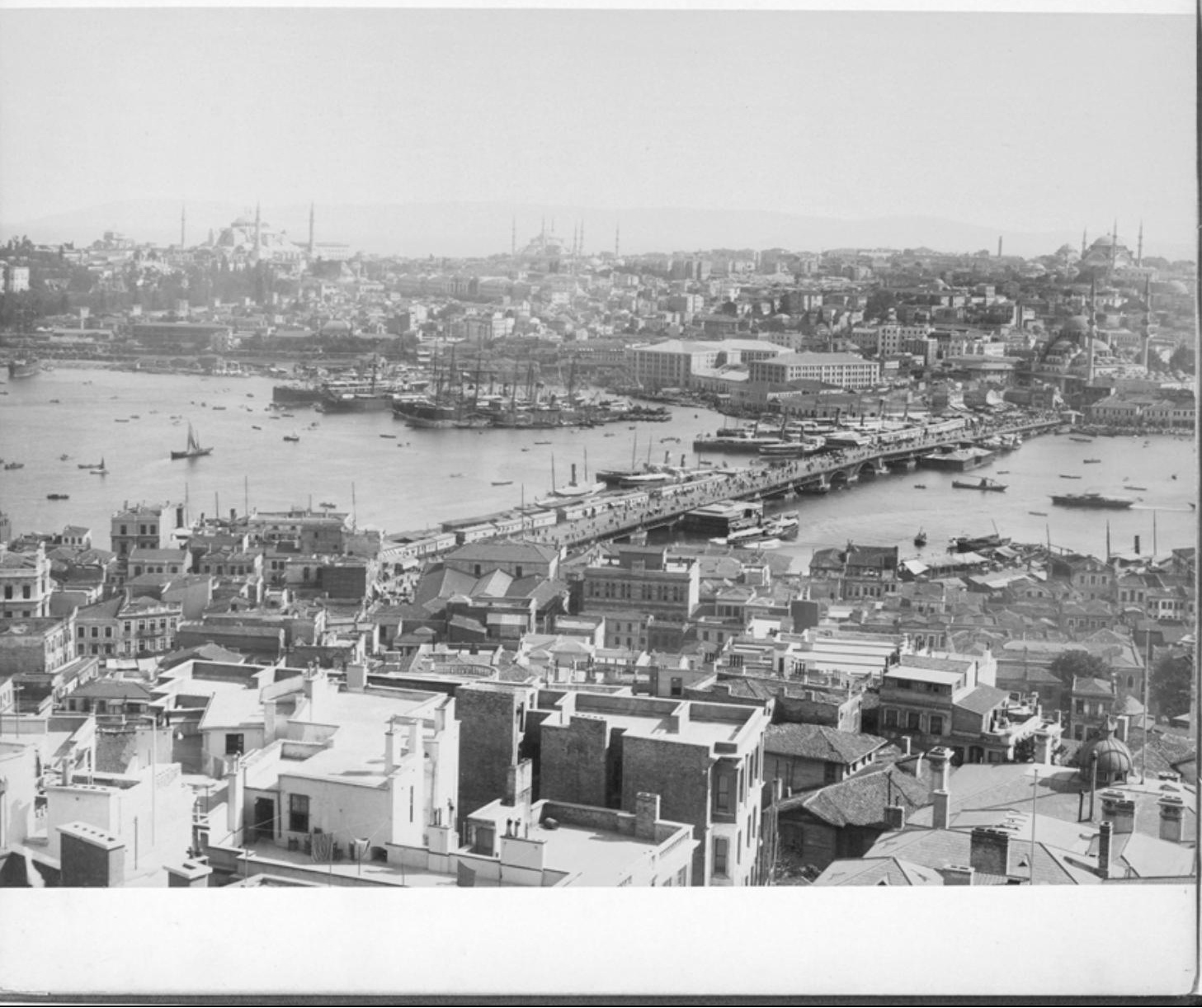

US Library of Congress Collection: prints and photograph 
The operative phenomena in the 2oth century Istanbul are mobility and transition. Mobility is represented in terms of the transmission of Rembetika to metropolitan Greece, primarily as a corollary of the displacement of Istanbul and Izmir Greeks from Thrace and Asia Minor. Musical transition takes place with the geographical displacement of the creators and performers of the Rembetika from Turkey to Greece, which precipitated a progressive leaching out of Turkish musical elements from lyrics and music, resulting in their Hellenization. Taken together, mobility in the guise of forced migration and musical transition, as the "rehoming" of Rembetika in the Greek world, are exemplary of exclusion and inclusion. In this case, geopolitics becomes destiny.

The time frame of 1900-1955 is meaningful for both the Ottoman/ Turkish milieu, in which Rembetika appears to have formed, and for the Greek milieus of Thessaloniki, Athens, and Piraeus, to which the Rembetika cultural forms of music, lyrics, and dance were transmitted. In the case of Ottoman/Turkish geopolitics, the beginning of the period signals the erosion of the Ottoman political and social order and its transformation and replacement by new dynamisms of republicanism, modernization, Westernization, and statism. We can usefully break down these fifty-five years into sub-periods, as follows: From 1900 to 1909 , which signals the establishment of the Young Turk order, from 1909 to 1923, which includes the defeat in the Great War, the collapse of the Empire, and the establishment of the Republic; from 1923 to 1945 , which covers the maturation of the Republican regime, the roll-back of Ottoman cultural forms and practices, and the emergence of a new geopolitical order in the Eastern Mediterranean and the Balkans following the convulsions of the Second World War. The final period terminates with the Cyprus crisis of 1955 and the anti-Greek riots that essentially bring to a close the Hellenic demographic story in Istanbul.

In the case of Greek geopolitics, the period 1900-1922/23 describes an extraordinary arc of geopolitical expansion followed by 
an equally dramatic collapse. The defeat of the Hellenic State by the newly formed Turkish Republic in 1922 stands as a catalytic moment for geopolitics, demography and cultural production: a large population and its culture was displaced and re-territorialized on the Hellenic mainland, with epicenters in the urban centers of Thessaloniki, Athens, and the port city of Piraeus. Rembetika is one of these cultural complexes that follow the exchangees.

The years that follow - roughly 1922-1934 - represent a period of adjustment and consolidation of the exilees qua diasporic communities in their new territorial bases. In 1922 Hellenism's "spores" of demography, culture, and property were slingshot by geopolitical circumstances "back" to a fairly newly constructed Hellenic State - barely one hundred years old at that point in time. The key fact here is that for the Greeks of Istanbul, Thrace, and Asia Minor, the country they encountered as refugees was an alien land, even if they essentially spoke the same language and belonged to the same church.

Finally, the years from the mid-1930s to 1955 are defined by a systemic - if not existential - struggle to annihilate Rembetika songs and life, and by extension, everything that did not ideologically and culturally conform to the reactionary definitions of modern Hellenism and Turkism of the period. In the 1930s Turkey and Greece were traveling along similar paths. Both state cultures defined themselves in opposition to the multiethnic, multi-vernacular, cosmopolitan, imperial, and regional cultural forms of the Ottoman world, and went to considerable length to contain, if not expunge, vestiges of Ottoman culture. A musical heritage that was a reflection of empire - not unlike the musical cultures of the $\hat{a} s ̧ ı s$ and the Zeybeks - clearly, Rembetika heightened the anxieties of Greek and Turkish nationalisms, which aimed at purity of cultural idiom. 
Figure 6: Greek-Orthodox population of Istanbul (former Constantinople) 1844-1997 ${ }^{9}$

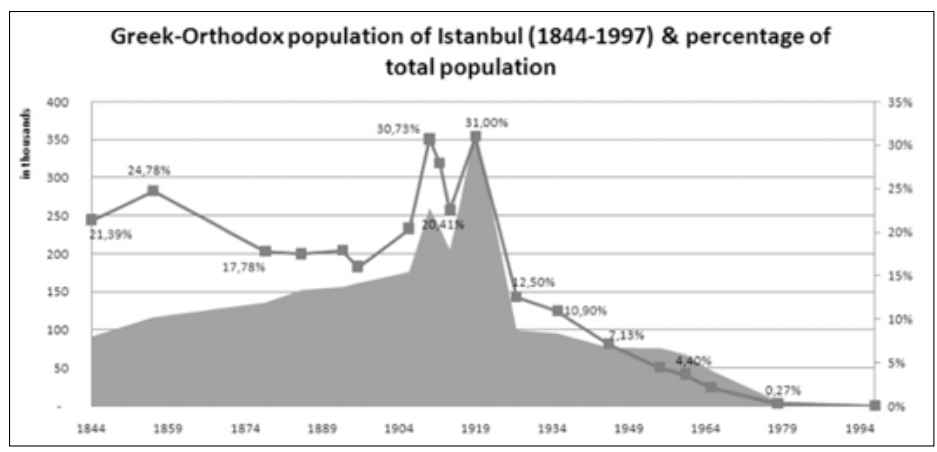

Savvas Tsilenis, with permission

\section{The Spatial Fix}

Although entirely urban in terms of its spatial fix, and flourishing in large centers like Istanbul and Izmir, Rembetika culture had a fraught relationship to modernity (at least as defined by the Tanzimat reforms). Here we encounter the rising importance of class among Ottoman religious minorities - the Rum (in the case of Istanbul, the Greek culture Orthodox community), the Armenians, and the

9 | Data drawn from Kamouzis Dimitrios (2010): The Constantinopolitan Greeks in the Era of Secular Nationalism, Mid-19th Century to 1930, Doctoral dissertation, London: University of London, King's College, Department of Byzantine and Modern Greek Studies, p. 32; Darja Reuschke/Monika Salzbrunn/Korinna Schönhärl (2013): The Economies of Urban Diversity: Ruhr

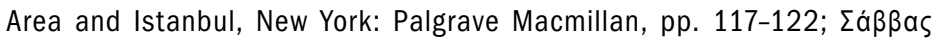

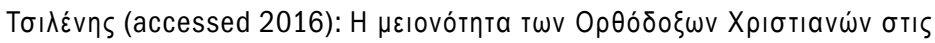

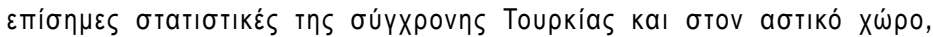
(Savvas Tsilenis, The Christian Orthodox Minority in Official Statistical Sources of Contemporary Turkey): http://www.demography-lab.prd.uth.gr/ DDAoG/article/cont/ergasies/tsilenis.htm 
Jews. Millet elites substantially embraced and benefitted from the rollout of Westernization after 1847 , while vastly greater segments of these same communities were not structurally incorporated in modernity and became increasingly marginalized. In the midst of a fast-transforming capital and region, socially marginal communities were increasingly becoming exposed to, and disciplined by a more assertive state and social forces of Western sensibility. In ways that mattered to the conduct of their everyday life - putting food on the table, avoiding violent death, sheltering safely in a home, experiencing love and loss, and preserving and enriching places of meaning - poor communities became "in-betweens," who faced the prospect of increased pressure to change and adapt, and, in extermis, of erasure.

The "where" of this Rembetika musical storytelling as emancipatory sensemaking (and placemaking) is at issue here. María Lugones offers the useful and adaptable construct of the "hangout" that spatializes the notion of public happiness, be it the construct of pleasure (of becoming visible to others as an equal, per Arendt) (Arendt, 1978: 36) or of fear (per Kristeva's critique of Arendt's argument about the bases for political bonding) (Kristeva, 2000: 180-81):

"Hangouts are highly fluid, worldly, non-sanctioned, communicative, occupations of space, contestatory retreats for the passing of knowledge, for the tactical-strategic fashioning of multivocal sense, of enigmatic vocabularies and gestures, for the development of keen commentaries on structural pressures and gaps, spaces of complex and open ended recognition. Hangouts are spaces that cannot be kept captive by the private/public split. They are worldly, contestatory concrete spaces within geographies sieged by and in defiance of logics and structures of domination." (Lugones 2003: 221)

As a phenomenon that did not attract the gaze of the state, there is very little specific information about the rembetes' whereabouts in imperial Istanbul. This is what we know: The Rembetika "hangouts" were likely located in Istanbul mahalles where most of the Greeks 
lived. These neighborhoods were rarely if ever culturally homogeneous. Behar describes how "the traditional mahalles of Istanbul were generally very mixed in terms of wealth, social class, and status. Residential patterns usually ran along lines of ethnicity and religion," although the degree of homogeneity of mahalles has been challenged in recent scholarship (Behar, 2003: 4-5). There were, however, "some mahalles where, on the whole, the inhabitants fared better than those of other neighborhoods ... Really 'exclusive' areas, or particularly well-off neighborhoods, or particularly destitute ones were quite exceptional" (Ibid). This is quite important in discerning the spatiality of Rembetika and the marginalized populations they created music for and about. First, the excluded rhapsodized by rembetes were often co-located with groups that were more socially integrated and upwardly mobile than themselves. Second, we know that Rembetika were identified with Greek urban communities like Fener, Galata and Péra, Tershané, Tarlabasi in Beyoglu, and Tatavla and the surrounds of the Kasım Paşa shipyards. (Savvas, 2016: online). The departure of the Greeks from these communities between 1922 and 1955 would signal the eradication of Rembetika "hangouts" as emancipatory (inclusive) spaces in Istanbul.

At the mahalle scale, a bricolage of old-agents of the Empire carried out functions of local control: The figures of çeribaşı, variously interpreted as descended from the demobilized sipahi/cavalry class, the local muscle and informal enforcer type (who Petropoulos calls "kapádai"), and the gendarme, or Western-styled policeman, representing the state, shared the security sphere and acted upon the public domain from different vantage points: The gendarme walked the beat, while the kapádai surveyed the mahalle from his chair at the café. The çeribaşı backed up the gendarme with his historical authority (Petropoulos, 1990: 13-15). All three represented late Ottoman masculinity at a time the Empire is being slowly dismantled by European Great Powers. Rembete masculinity, as we know, possesses its own distinctive performances, situated it in opposition to that of the local heavies. 
Figure 7: "This map indicates the general results of investigations concerning the national complexion of various parts of the city. It is not based upon a house-to-house survey and therefore it can be regarded only as approximately accurate. There is more or less intermingling of nationalities in every section" (Goodsell, 1922)

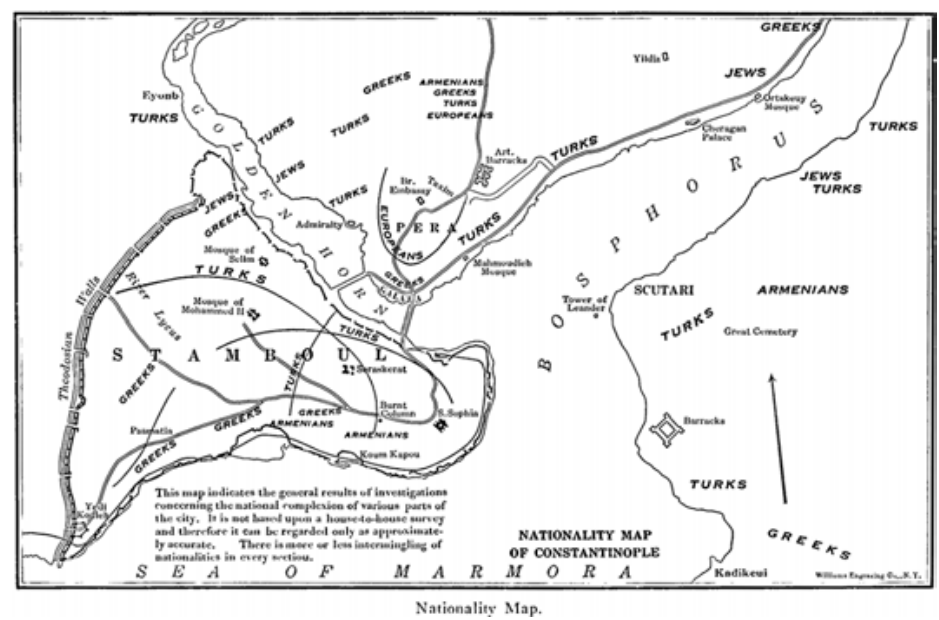

The MacMillan Company, with permission

As Petropoulos suggests, the balance of power between the formal state and such informal local enforcers was very delicate, though nothing of great importance to the state would take place here. Our paradigmatic neighborhood was socially marginal. Porterage, fishing (if also on the urban littoral), petty industry mostly on the Golden Horn side, small commerce including hole-in-the-wall cafés and taverns, petty crime, and "sin" industries, defined the occupational mosaic. By century's end the traditional spatial-sectarian segregation in the city was gradually giving way to segregation by class.

The urban, and occasionally suburban, establishments where rembetes performed their music, ranged from hole-in-the wall cafés, taverns that would set up a so-called 'palko' or dais for the night's performance, and clubs that ranged from simple loft spaces over 
taverns to actual storefront establishments. In the case of "suburban" clubs, free standing buildings - sometimes either just shacks or more permanent facilities - would be erected. Holst records the reminiscences of old rembetes who described them as “... cafés ... on various levels of sophistication, but the standard type was called the Café Aman, probably a corruption of the Turkish Mani Kahvesi, a café where two or three singers improvised on verse, often in the form of a dialogue with free rhythm and melody ... In the early Greek Café Amans, there would simply be a space left at one end of the café for musicians" (Holst, 1994: 20). ${ }^{10}$

In all, then, the urban is implicated in each one of these scales micro-scale of bodyspace, the meso-scale of the mahalle and its performance places, and the macro-scale of the state-in-transformation. The urban is neither mere stage nor context for the Rembetika passion play. A certain kind of state and a certain kind of city create and enable Rembetika by incubating marginality, and Rembetika operates as part entertainment, as part salve, as part resistance.

10 | Ultimately, there is much more information about rembetika establishments in Greece than in pre-1922 Istanbul. Over the years that follow the forced migration of 1922, rembetika assume more and more the characteristics of small business. Petty capitalists - almost never the rembete performers - would set up clubs, which in some cases would be patronized by urban elites not unlike the way whites patronized blues and jazz clubs in black neighborhoods before desegregation in the United States. Their association with rembetika and the social mix that produced them gave those communities a certain degree of notoriety: Kokkinia and Troumba in Piraeus, Tzitzifies and Faliro in Athens, Vardaris in Thessaloniki are closely associated with rembetika culture. Because of the market efficiencies achieved through what urban geographers would call 'agglomeration economies', these same neighborhoods were low-rent bright lights districts that alongside fleets of bars they featured brothels and blue movie theaters. In another sense, such neighborhoods are materially similar to the American skid row but not associated with the dynamics of the central business district. 
Figure 8: (Map detail) The Christian quarters appear in grey. Militärgeographisches Institut der österreichisch-ungarischen Monarchie aus den Jahren (1860-70): "Konstantinopel, Péra, Skutari, Goldenes Horn, südlicher Bosporus, aus der Generalkarte der europäischen Türkei und Griechenlands."

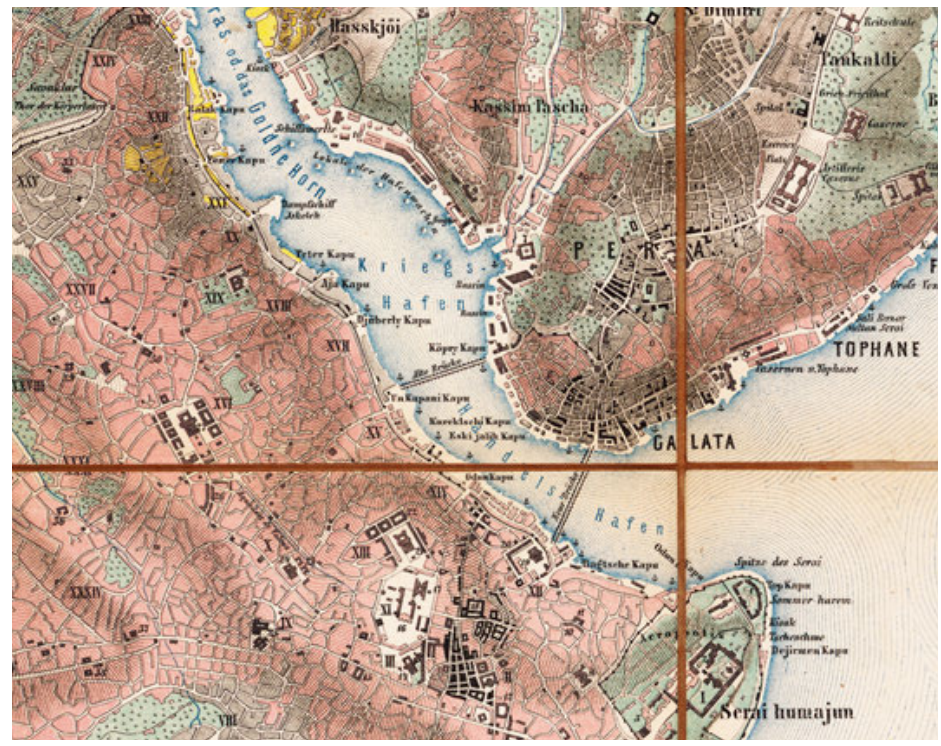

Wikimedia Commons 
Figure 9: Petropoulos poses for the camera in August 25, 1973 with brothers Karolos and Nikos Milanos, the owners of the rembetes café "Skala" (a tongue-in-cheek reference to the Scala of Milan) in the city of Volos. Their father, Stefanos, opened the café in 1963 (Petropoulos, 1991: 400)

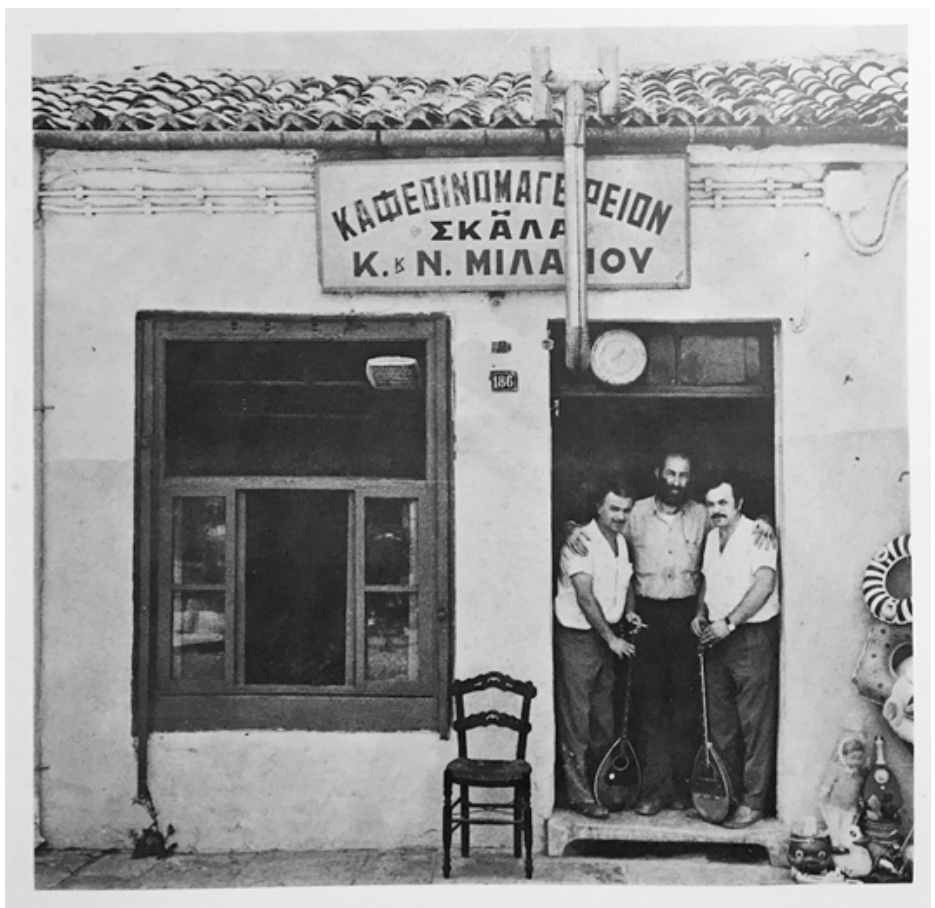

Kedros Editions, with permission 


\section{Rembetika LandSCAPES OF INCLUSION AND EXCLUSION}

Starting in the middle of the 19th century, industrial modernity and Great Power geopolitics impacted all social strata, from Ottoman elites to the Europeanized classes at the Péra, all the way down the social ladder to the urban poor. When Westernization, modernization, industrial capitalism, and European ideas of social development supplanted the sectarian structure of Ottoman society with new class dynamics, new polarities of home and work, politics, and identities, marginalized urban populations - especially nonMuslims - were further alienated and left behind. Rembetika as music genre and heteroclite state of the mind and life gave voice to marginalized Istanbul Greek minority ethnics during the twilight of the Ottoman Empire. Rembetika is their song of sorrow, protest, and resistance. The rembetes embodied life and music - coded in a body schema that at times negotiated and at times clashed with the changing city - defied social, behavioral, and artistic conventions. As such Rembetika is music of transition, because the externalities of change and transition served as muse. In giving voice to the dispossessed, Rembetika created inclusion and expressed resistance to exclusion, if not durably, then through ephemeral acts of defiance.

In the city's soundscapes, on the one hand the waltz, and on the other, Rembetika and amané, did not readily mix as parts of the city adopted western forms and modes and others did not. I do not suggest that Rembetika was not cosmopolitan. It reflected a Balkan and Eastern Mediterranean cosmos, as opposed to the dominant cosmos constructed in Paris, London, Berlin, Vienna, and SaintPetersburg. Although musically the Rembetika originate in the East (in Istanbul and Izmir primarily), it was only after their transmission to Greece, post-1922, that Rembetika would assume a form in which it would endure, albeit commodified, to the present day. Brought to the Greek mainland from Istanbul and Izmir neighborhoods, Rembetika is a musical genre in transition - a transition to a more profoundly Hellenized Rembetika genre catalyzed by forced 
migration. It is accented, flavored, and emboldened by the persistence of socio-spatial marginality and censorship in the new Greek homeland, as much as by the trauma of lost homesteads and homelands in Asia Minor.

Until its transmutation into a commodified, popular Greek musical genre in the 1960 s, Rembetika, when visible to the gaze of the state, was disapproved of, censured, banned, and threatened with annihilation. Rembetika was constructed by illiberal regimes in Turkey and Greece of the 1930 into a political (or at least politicized) art form that threatened state ideas of occidentality, Europeanness, and modernity. As such, Rembetika songs about exclusion transformed dive clubs and shanties into empowering - and inclusive - landscapes.

I would like to thank Elizabeth Kelly for her much needed editorial interventions, encouragement, and good counsel, and the editors of Kedros Publishing, Athens, for kindly allowing the reproduction of several of the images in this chapter.

\section{Works Cited}

Alexatos, Yiorgos (2014): The song of the defeated: Social contradictions and popular song in postwar Greece, Athens: Ekdoseis

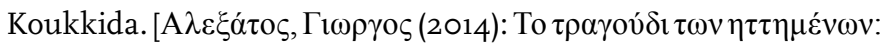

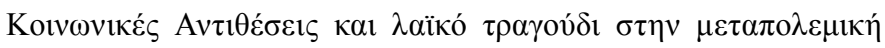

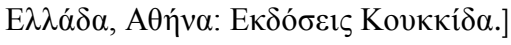

Anogeianakis, Foibos (1947): “The Rembetika song." In: Rizos-

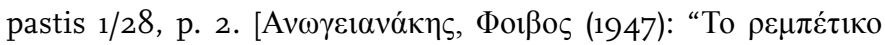

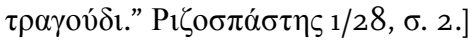

Arendt, Hannah (1958/1998): The Human Condition, 2nd Edition, Chicago: The University of Chicago Press.

Arendt, Hannah (1978): Life of the Mind: Thinking, New York: Harcourt Brace Jovanovich. 
Behar, Cem (2003): A Neighborhood in Ottoman Istanbul. Fruit Vendors and Civil Servants in the Kasap Ilyas Mahalle, Albany, NY: State University of New York Press.

Çelik, Zeynep (1984): “Bouvard's Boulevards. Beaux-Arts Planning in Istanbul." In: Journal of the Society of Architectural Historians, 4/43, pp. 341-355.

Damianakos, Stathis (2001): The sociology of Rembetika, Athens:

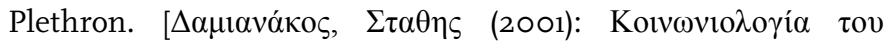

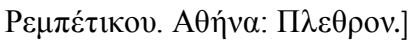

de Beauvoir, Simone (2010): The Second Sex (trans. C. Borde and S. Malovany-Chevallie), New York: Alfred A. Knopf.

Gail Holst, Gail (1994): Road to Rembetika. Music of a Greek SubCulture - Songs of Love, Sorrow and Hashish 3rd edition. Limni, Evia, Greece: Denise Harvey (Publisher).

Gauntlett, Stathis (2001): Rembetika song: A Contribution from a scientific perspective, Athens: Ekdoseis tou Eikostou Protou

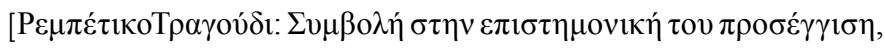

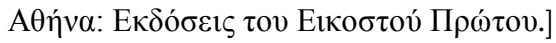

Goodsell, Fred Field (1922): “Historical Setting." In: Clarence Richard Johnson (ed.), Constantinople To-Day, or, The Pathfinder Survey of Constantinople: A Study in Oriental Social Life. New York: The MacMillan Company.

Hart, Mechthild (2013): "Laboring and Hanging Out in the Embodied In-Between.” In: Hypatia 28/1, pp. 49-68.

Kamouzis, Dimitrios (2010): The Constantinopolitan Greeks in the Era of Secular Nationalism, Mid-19th Century to 1930, Doctoral dissertation, London: University of London, King's College, Department of Byzantine and Modern Greek Studies.

Katharine Butterworth/Sara Schneider (eds)(2014): Rebetika. Songs from the Old Greek Underworld, 2nd edition, Athens: Aiora Press.

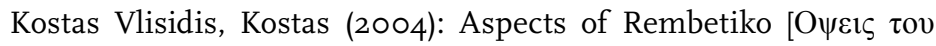
$\rho \varepsilon \mu \pi \varepsilon \tau \iota \kappa o v]$, Athens: Ekdoseis tou Eikostou Protou.

Kristeva, Julia (2000): Hannah Arendt (trans. Ross Guberman), New York: Columbia University Press. 
Liavas, Lampros (1996), "The purification of Rembetika. From the teké to the tavern and from the dive bar to the "club'." In:

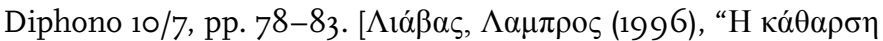

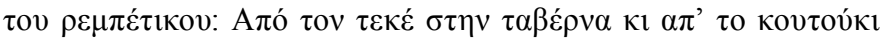

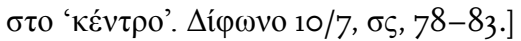

Manuel, Peter (1989): "Modal Harmony in Andalusian, Eastern European, and Turkish Syncretic Musics." In: Yearbook for Traditional Music 21, pp. 70-94.

Merleau-Ponty, Maurice (2013): Phenomenology of Perception, New York: Routledge, Kindle Edition.

Paloglou, Sophia-Maria (2016): Trajectories of music as experienced in clubs that operated between 1947 and 1967: The case of Nikaia (Kokkinia), Doctoral dissertation, Athens: Greece: Harokopeio University, School of Environment, Geography and Applied Economics, Department of Household Economics and Ecology.

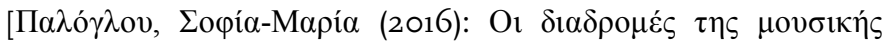

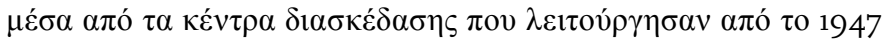

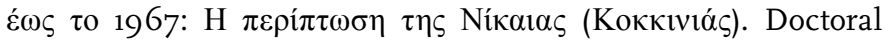

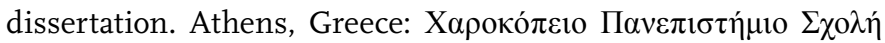

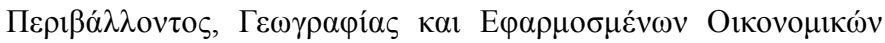

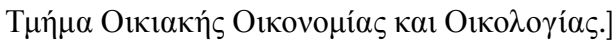

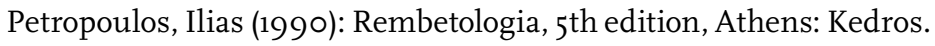
Petropoulos, Ilias (1991): Rembetika Songs, 11th edition, Athens: Kedros.

Reuschke, Daria/ Salzbrunn, Monica/ Schönhärl, Korinna (2013): The Economies of Urban Diversity: Ruhr Area and Istanbul, New York: Palgrave Macmillan.

Samson, Jim (2013): Music in the Balkans. Leiden, NL: Brill.

Savvopoulos, Panos (2010): Regarding the term 'rembetiko' and

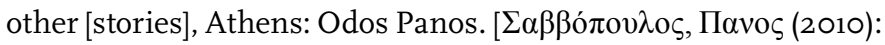

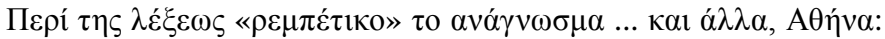

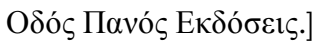

Sebah \& Joaillier, photographer (1890-1910): Panorama de Constantinople, pris de La Tour de Galata. Washington, DC: Library of 
Congress Prints and Photographs Division, Library of Congress Control Number 2007660407 .

Sevin Aksoylu, Sevin/Ateş, Sevim (7/2013): "Changes in the Historical Layout of Cities in Turkey Related to Modernization Movements and the Dissemination of Foreign Planning Concepts" In: Proceedings of the IGU Urban Geography Commission, pp. 12-26.

Tsilenis Savvas, "Topography of Ottoman Constantinople (Istanbul)“, Encyclopaedia of the Hellenic World, Constantinople, URL: http://www.ehw.gr/l.aspx?id=11394

Tsilenis, Savvas (accessed 2016): The Christian Orthodox Minority in Official Statistical Sources of Contemporary Turkey [H $\mu \varepsilon$ covó $\tau \eta \tau \alpha$

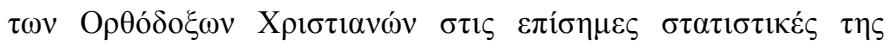

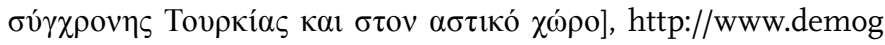
raphy-lab.prd.uth.gr/DDAoG/article/cont/ergasies/tsilenis.htm

Vidal de la Blache, Paul (1922): Les Principes de Géographie humaine, Paris: A. Colin.

Vlisidis, Kostas (2004): Perspectives on rembetiko, Athens: Ekdoseis

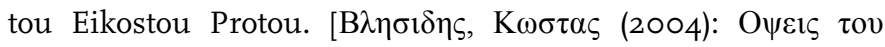

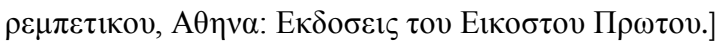

Vlisidis, Kostas (2011): The KKE [Communist Party of Greece] on Rembetika: A dialogue in Rizospastis." Ardin 86/6-7, p. 64.

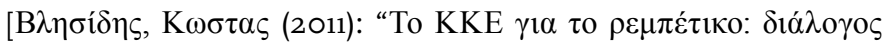

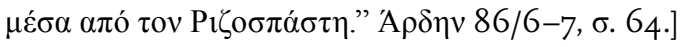

Yerasimos, Stephanos (1996): “Tanzimat'in kent reformlari üzerine.” In: P. Dumont/F. Georgeon (eds.), Modernlesme sürecinde Osmanli kentleri, Istanbul: Tarih Vakfi Yurt Yayinlari, pp.1-18. 
